In Submarine Mass Movements and their Consequences Volume 41 of the series Advances in Natural and Technological Hazards Research pp 321-329

2016

Eds Lamarche, G., Mountjoy, J., Bull, S., Hubble, T., Krastel, S., Lane, E., Micallef, A., Moscardelli, L., Mueller, C., Pecher, I., Woelz, S.

http://dx.doi.org/10.1007/978-3-319-20979-1 32

http://archimer.ifremer.fr/doc/00349/46066/

(c) Springer International Publishing Switzerland 2016

\title{
Pleistocene Mass Transport Deposits Off Barbados Accretionary Prism (Lesser Antilles)
}

\author{
Pichot Thibaud ${ }^{1,2,{ }^{*}, \text { Lafuerza Sara }}{ }^{3}$, Patriat Martin ${ }^{1}$, Roest Walter ${ }^{1}$
}

${ }^{1}$ IFREMER, Ctr Brest, Geosci Marines, ZI Pointe Diable, CS 10070, F-29280 Plouzane, France.

2 Beicip Franlab, 232 Ave Napoleon Bonaparte,BP 213, F-92502 Rueil Malmaison, France.

${ }^{3}$ Fugro Geoconsulting SAS, 39 Rue Peupliers, F-92752 Nanterre, France.

*Corresponding author : Thibaud Pichot, email address : thibaud.pichot@gmail.com

\begin{abstract}
:
Two Pleistocene mass transport deposits (MTDs), with volumes of thousands of $\mathrm{km}(3)$, have been identified from multi-channel seismic data in the abyssal plain at the front of the Barbados accretionary prism. Estimated sediment volumes for these MTDs are likely underestimated due to limited seismic coverage. In this work, we suggest that these MTDs are comparable in size to large submarine landslides as reported in the literature. These MTDs lie on the vicinity of two major oceanic ridges, the Barracuda Ridge and the Tiburon Rise. It is also suggested in this work that the MTDs come from seismicity associated with the formation of the Barracuda Ridge or the Barbados accretionary prism; however, triggering mechanisms involved in their formation remain uncertain. The present study discusses the potential causal factors accounting for the formation of these MTDs.
\end{abstract}

Keywords : Lesser Antilles subduction zone, Barbados accretionary prism, Mass transport deposits, Subducted oceanic ridges

\section{Introduction}

The Lesser Antilles volcanic arc and the Barbados accretionary prism have been created by the subduction of the oceanic lithosphere of the North America and South America plates beneath the Caribbean plate (Fig. 1). In the forearc domain, numerous localised submarine landslides have been described mostly in the southern part of the Barbados accretionary prism (Sumner and Westbrook, 2001; Deville et al., 2015). At the latitude of Anguilla and Martinique islands, the 
Barbados accretionary prism is located above the diffuse plate boundary (between North America and South Amercia). As a result of local readjustments of the oceanic lithospheres, two ridges are derived from oceanic fracture zones that were uplifted in the Middle-Late Miocene (Tiburon Rise) and the early Pleistocene (Barracuda Ridge) (Patriat et al., 2011; Pichot et al., 2012). Of these two ridges, the Tiburon Rise is currently subducting and creating roughness in the downgoing plate beneath the accretionary prism.

This study uses seismic reflection data, multibeam bathymetry data and published borehole data to evaluate the origin of two giant MTDs. We present an age estimation for these MTDs and we also discuss the potential triggering mechanisms that could be associated with their emplacement. 


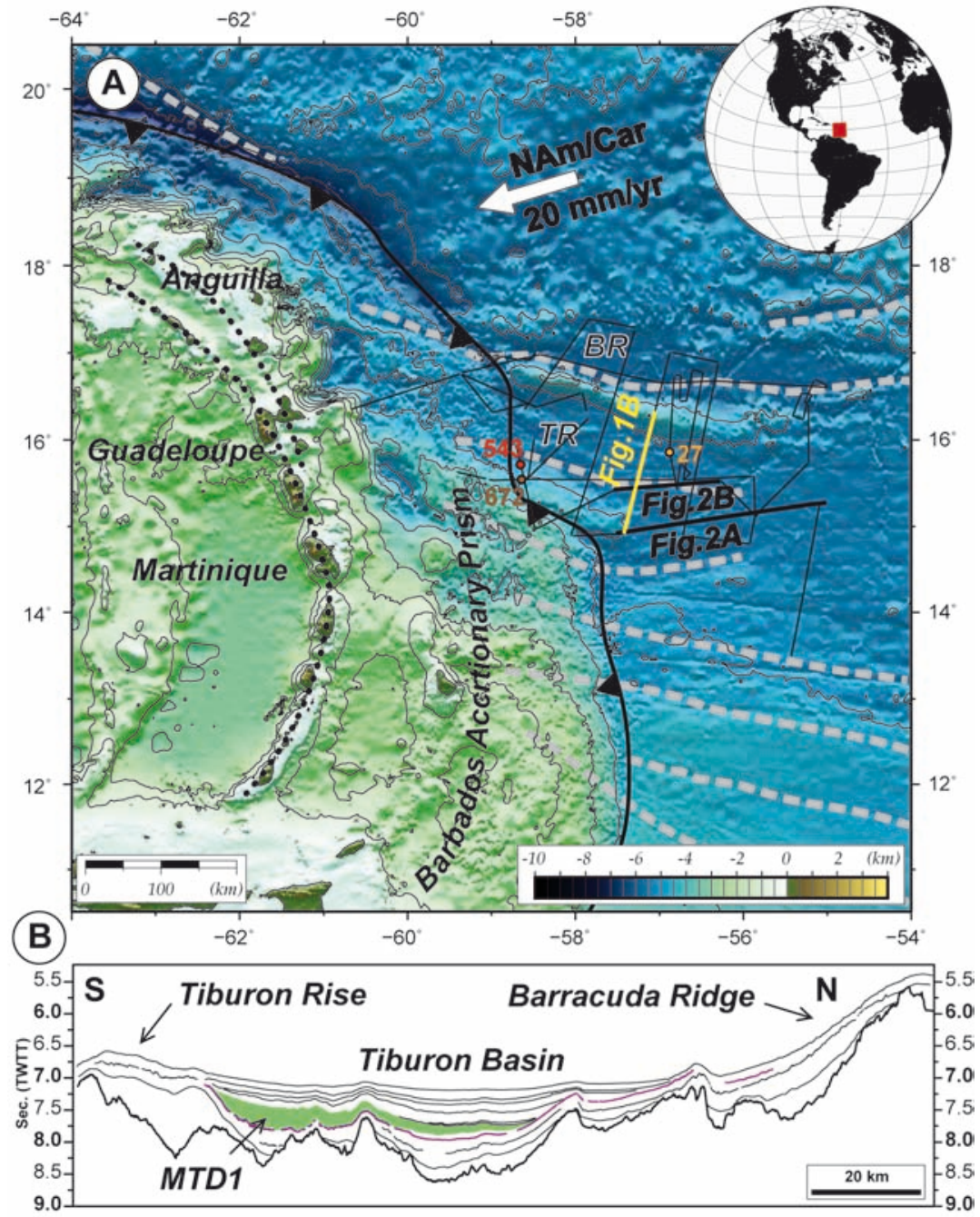

Fig.1. A) Bathymetric map (Smith and Sandwell, 1997). Grey dashed lines; fracture zones (from Pichot et al., 2012). Black dots; volcanic arc. ANTIPLAC seismic profiles are indicated by black lines. TR, Tiburon Rise, BR, Barracuda Ridge. The DSDP-ODP drilling sites 27, 543 and 672 are shown by colored dots. NA/Car; North America - Caribbean relative plate motion. B) Interpretation of seismic profile crossing the Tiburon Basin. Thick black reflector; acoustic basement. Purple reflector; unconformity at the base of the quaternary sequence (H02).

\section{Data and Methods}




\subsection{Geophysical data}

The data used in this study were acquired during the ANTIPLAC Cruise conducted by Ifremer in 2007 in offshore Martinique and Guadeloupe. The survey consisted of $4160 \mathrm{~km}$ of multi-channel seismic reflection and multibeam bathymetry data (Fig. 1). Additional multibeam bathymetry data compiled from different sources for the ANTIPLAC program (Pichot et al., 2012) has been also used. The seismic data experiment was comprised of a 24-channel streamer and two generator injector air guns with a total volume of $300 \mathrm{in}^{3}$. Two additional seismic lines provided by the NOC (courtesy of Alan Evans), have also been used for this study (lines DM127 and EP129, Fig. 1).

\subsection{Seismic Calibration based on borehole data}

The Demerara Abyssal Plain adjacent to the Barbados accretionary front has been subject of several drilling legs in the past, among them: DSDP leg 4 Site 27 (1969), leg 78A Site 543 (1981) and ODP legs 110 Site 672 (1986) (Fig.1). The ANTIPLAC cruise was designed to cross these DSDP-ODP drilling sites. Because of the highest amount of quaternary sediments recovered at Site 27 (Bader et al., 1970) this site is of particular importance to study recent sedimentation processes occurring seaward of the Barbados accretionary prism. Considering velocity laws from previous studies in the area (Bangs et al., 1990; Dolman, 2000), borehole depth and stratigraphic boundaries reported at Site 27 were converted into time (Patriat et al., 2011; Pichot et al., 2012;). This allowed us to calibrate borehole data into de seismic profiles to estimate the age of the MTDs (Fig. 2d).

\section{Results}

The available seismic data shows a Quaternary sequence characterized by continuous, well-stratified seismic reflectors of weak and strong amplitude (Fig. 2). According to the stratigraphic record reported at Site 27 (Bader et al., 1970) and other regional studies (Wright et al., 1984; Dolman, 2000), the quaternary succession generally comprises interbedded distal turbidites within hemipelagic sediments. The Quaternary sequence onlaps against a progressive unconformity (horizon H02) (Fig. 1), which marks the onset of the Barracuda ridge uplift (Patriat et al., 2011; Pichot et al., 2012). Two bodies with chaotic seismic facies have been identified south of the Barracuda Ridge and east of the Tiburon Rise (Fig. 2). MTDs are named here, from oldest to youngest, as MTD1 and MTD2. Both bodies show erosional basal surfaces and are interpreted as MTDs (Fig. 2c). It is not known if these MTDs were multistage or emplaced as single events. 

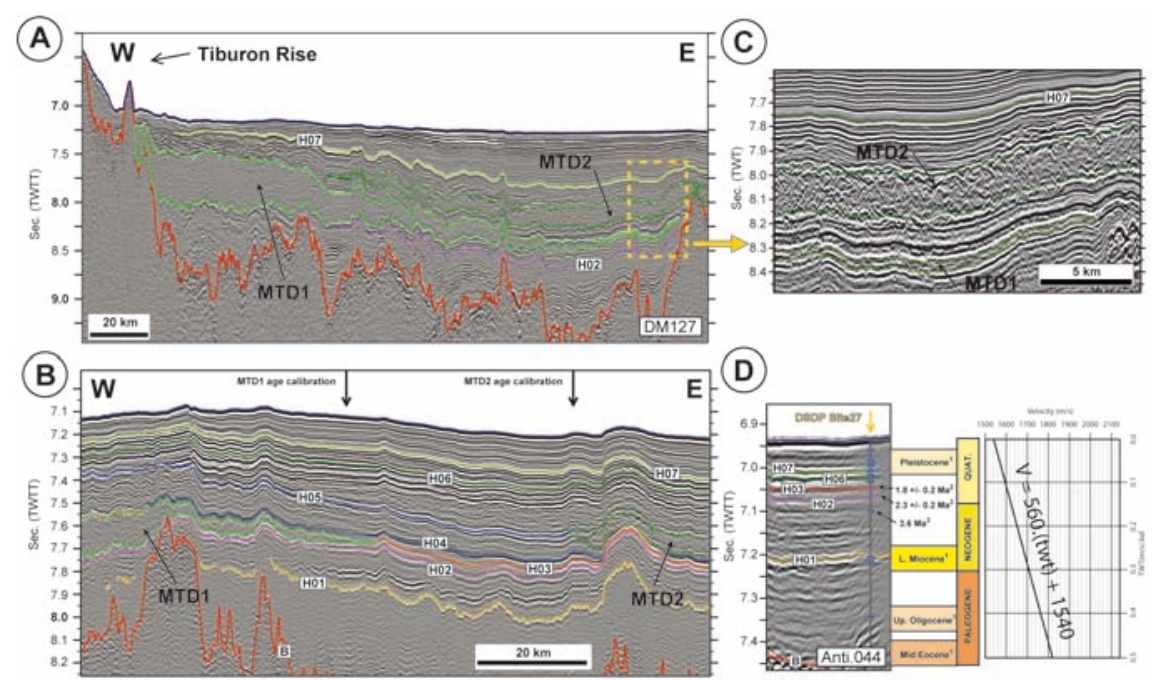

Fig. 2. A) Seismic profile DM127 showing MTD1 and MTD2. B) Seismic section Anti-015 showing quaternary horizons discussed in the text. The black arrows indicate the positions where the age calibration has been estimated. The red reflector refers as the acoustic basement. C) Zoom of the MTDs seismic facies. D) Correlation of section Anti-044 with the DSDP site 27 borehole. The ages are from Bader et al. (1970; superscripts 1) except for H03 (This study; superscripts 2), H02 and earlier marker (Patriat et al., 2011; superscripts 3). Blue marks is the top of cored intervals at Site 27. The velocity low used for time to depth conversions is also indicated.

The relative ages of these MTDs were estimated by considering the timing of seismic horizons that define their bases and tops. This approach considers that MTD1 is bounded by horizons H02 and H03 (Fig. 2b). According to Patriat et al. (2011), H02 is $2.3 \pm 0.2 \mathrm{Ma}$ at Site 27, using the velocity law shown in Figure 2c and considering a sedimentation rate of $4 \mathrm{~cm} / \mathrm{ka}$ (Sigurdsson et al., 1980). The same sedimentation rate has been assumed for the interval comprised between $\mathrm{H} 02$ and $\mathrm{H} 03$ (at line Anti-015, Fig.2b). Accordingly, we estimate the age of H03 as $1.8 \pm 0.2 \mathrm{Ma}$ at Site 27 . The base of MTD1 is approximately located $0.022 \mathrm{~s}$ (TWT) above H02 (see arrow in Fig. 2b), which corresponds to $24 \mathrm{~m}$ according to the velocity profile that was used. Considering a minimum sedimentation rate of 4 $\mathrm{cm} / \mathrm{ka}$, it is inferred then that the base of MTD1 is younger than 2.0 $\pm 0.2 \mathrm{Ma}$.

Sedimentation rates of $4 \mathrm{~cm} / \mathrm{ka}$, used at Site 27, cannot be applied for the quaternary sediments above seismic horizon $\mathrm{H} 03$ (Line Anti-015, Fig. 2b, 2d). For the interval between the seafloor and H03, where MTD2 is located, a mean sedimentation rate of $28 \pm 4 \mathrm{~cm} / \mathrm{ka}$ was used (uncertainty calculated from the vertical resolution of the multi-channel seismic data of $10 \mathrm{~m}$ ). Sediment thickness between $\mathrm{H} 03$ and the base of the MTD2 is $\sim 114 \mathrm{~m}$ ( $\sim 0.10 \mathrm{~s}$ TWT, Fig. $2 \mathrm{~b})$, which provides an age of the MTD2 base of $1.4 \pm 0.3$ Ma. If the thickness between $\mathrm{H} 03$ and the top of the MTD2 is $\sim 142 \mathrm{~m}(\sim 0.14 \mathrm{~s}$ TWT, Fig. $2 \mathrm{~b})$ the resulting age of 
the MTD2 top is $1.3 \pm 0.3 \mathrm{Ma}$. The time of formation of MTD2 can then be bracketed between 1.3 and $1.4 \pm 0.3 \mathrm{Ma}$. The uncertainties provided here are too large to precise if these MTDs were deposited as the result of a multiphase event or as part of one single episode of mass wasting..

The available seismic data does not cover the entire extent of these MTDs and therefore only minimum estimates of their areal distribution could be provided as part of this work (Fig. 3c). According to these estimates MTD1 and MTD2 cover minimum areas of $15 \cdot 10^{3}$ and $19.6 \cdot 10^{3} \mathrm{~km}^{2}$ respectively. Both MTDs thin northwards reaching maximum thicknesses of $0.5 \mathrm{~s}$ (MTD1) and $0.4 \mathrm{~s}$ TWT (MTD2) (Fig. 3c). Erosional surfaces defining the base of these MTDs are more significant in the south whereas these units lie conformably above older sediments toward the north (Pichot et al., 2012). Taking into consideration the relative location of the Barracuda Ridge and the Tiburon Rise, and the partial thickness trends and areal distribution observed in the seismic data, we hypothesized that the source area for MTD1 might be located in the eastern edge of the Tiburon Rise. On the other hand, the source area for MTD2 remains still speculative even though it is our assumption that the source for this unit is located toward the south. Minimum estimated sediment volumes for MTD1 and MTD2 are 1800 and 2600 $\mathrm{km}^{3}$ respectively. Sediment compaction curves were not taken into consideration when these calculations were performed.

\section{Discussion}

\subsection{Slope instability at oceanic ridges}

Submarine landslides generated along slopes of oceanic highs have already been described by a multitude of authors (Pimm et al., 1972; Kristoffersen et al., 2007; Rodriguez et al., 2012). The fact that MTD1 is located at the edge of the eastern flank of the Tiburon Rise would point to the uplift of this rise as a potential trigger. However, the uplift of the Tiburon Rise occurred in the Middle-Late Miocene long before the estimated emplacement of MTD1 (Pichot et al., 2012). This indicates that MTD1 was not generated during the main phase of uplift associated with the Tiburon Rise; instead a more recent seismic event could have destabilized the flanks of the Tiburon Rise triggering the formation of MTD1. It is interesting to notice that the timing of both MTDs is close to the time of uplift of the Barracuda Ridge at 2.3 Ma (Pichot et al., 2012); however, seismic and bathymetry data do not suggest that the source area for these units is linked to this structure (no headwall escarpments or other erosional features indicates that mass wasting affected the Barracuda Ridge). Even though no clear evidence exists to state that these MTDs were sourced from the Barracuda Ridge, it is possible that 
seismicity associated with the emplacement of this structural high could have affected the stability of the adjacent Tiburon Rise triggering the formation of these units.
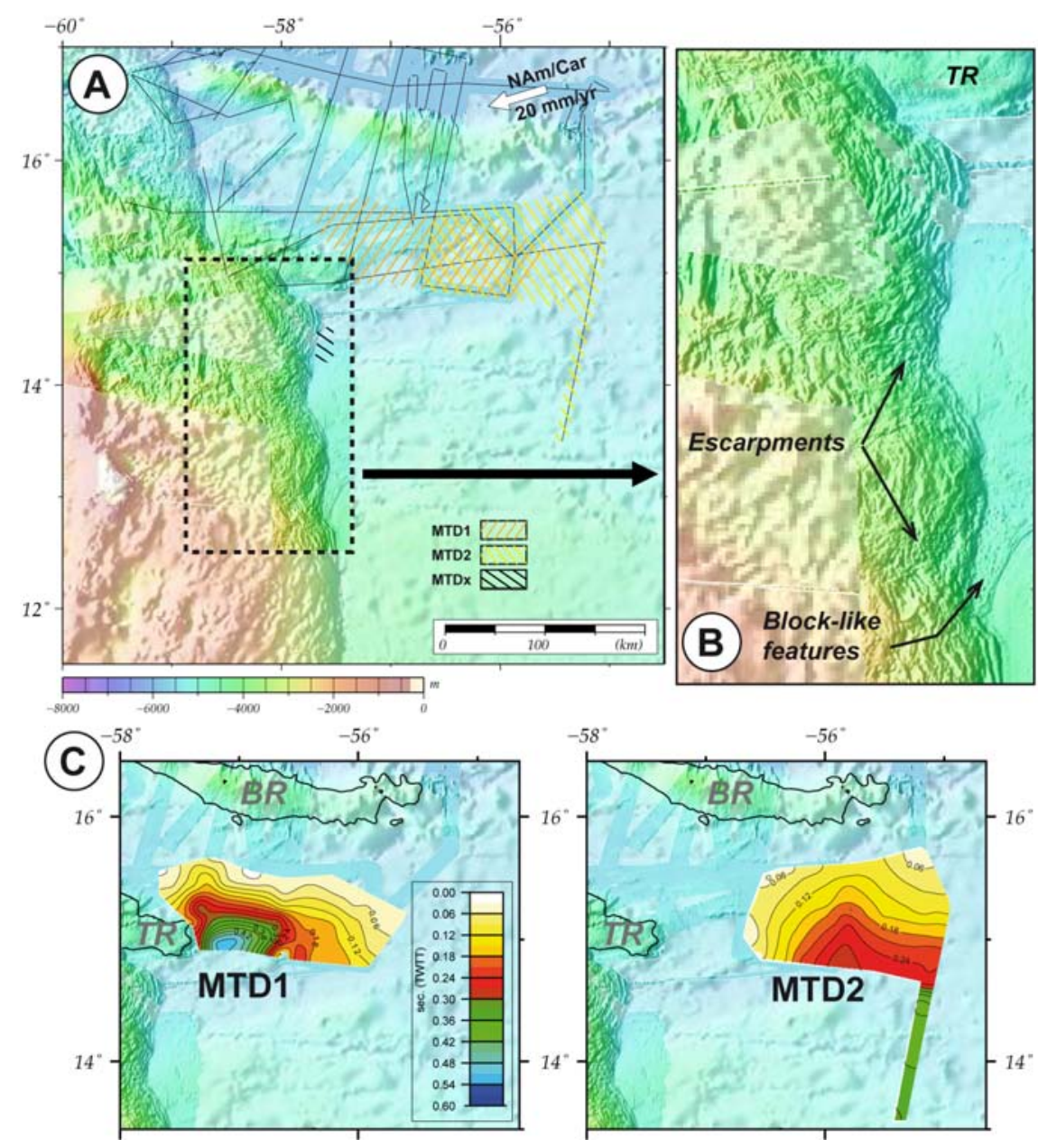

Fig. 3. A) Combined multibeam bathymetric and satellite altimetry (Smith and Sandwell, 1997) map showing the area covered by MTD 1 and MTD2. MTDx refers to the slump deposit described by Sumner and Westbrook (2001). B) Zoom of the Barbados accretionary front showing destabilization features. C) Isopach maps of each MTD showing their spatial distribution. Note that the thickness is in two way travel time (TWTT).

\subsection{Slope instability at Barbados accretionary prism}


Sumner and Westbrook (2001) described a deposit located to the east of the Barbados accretionary front that presents seismic facies that are similar to those observed within the studied MTDs (Fig.3a). This deposit, referred as slump deposit, was dated between 1.8 Ma and 1.1 Ma. Both, the seismic facies and the age of this slump deposit coincide well with the MTDs we described further north. A direct link between them is not clear because of the lack of seismic data between the two areas. It is unlikely that all these events were part of a single unit but it is possible that these MTDs were formed during the same time period. The suggestion is that broad slope instability processes at the beginning of the Quaternary affected the Barbados accretionary prism. Additional multibeam bathymetry data available for the ANTIPLAC program shows spectacular features of destabilisation of the front of the prism between $13^{\circ} \mathrm{N}$ and $14^{\circ} \mathrm{N}$ (Fig. 3c). Adjacent to these escarpments, the seafloor presents numerous block-like features that can be attributed to MTDs running toward the northeast. The presence of these deposits strengthens the hypothesis that slope instabilities affected the Barbados accretionary prism. The geometry of the distal part of the studied MTDs reveals that the frontal part of the MTDs thins progressively towards the north and lies between parallel-stratified reflections. No compressional features such as reverse faults have been observed in the frontal part of these MTDs. They seem to be translated in an unconfined way over the seafloor, which could suggest relatively long travelled distances. It seems plausible therefore that the Barbados accretionary prism might also constitute a source area for MTD1 and MTD2 and we offer this hypothesis as an alternative interpretation.

\section{Conclusions}

Two MTDs (MTD1 and MTD2) were interpreted near the Barbados accretionary prism using seismic reflection and multibeam bathymetry data. The minimum areal extension of these MTDs ranges from $15 \cdot 10^{3}$ to $19.6 \cdot 10^{3} \mathrm{~km}^{2}$ and their minimum estimated sediment volumes range from 1800 to $2600 \mathrm{~km}^{3}$. Borehole data allowed us to bracket the age of the MTD1 and MTD2 between 2.0 to $1.8 \pm$ $0.2 \mathrm{Ma}$ and 1.4 to $1.3 \pm 0.3 \mathrm{Ma}$, respectively. Determination of exact source areas for these events remains unclear due to lack of proper seismic coverage. However, we developed two hypotheses that explore potential triggering mechanisms and source areas for these units. Hypothesis 1 suggests that MTD1 was derived from the Tiburon Rise as suggested by stratigraphic relationships observed in one of the seismic lines (Fig. 2a); however, potential triggering mechanisms for MTD1 are associated with seismicity related to the later uplift of the Barracuda Ridge. Hypothesis 2 suggests that both MTDs were sourced from the Barbados accretionary prism to the south where similar looking MTDs have been imaged using multibeam bathymetry and satellite altimetry data. Hypothesis 2 also implies that triggering mechanisms are associated with seismicity associated with the formation of the Barbados accretionary prism. These working hypotheses need to 
be confirmed by the acquisition and examination of more extensive data sets that will allow for the proper mapping of these units.

Acknowledgments The authors sincerely thank Benoit Loubrieu for multibeam processing and Alan Evans for providing additional seismic profiles. We thank the government of Barbados and notably its ministry of Foreign Affairs to have given permission to use their seismic reflection data in this paper. Alan Evens of the National Oceanographic Centre, Southampton, facilitated the access to this data set. We strongly thank Jean-Yves Collot, Christian Beck and Lorena Moscardelli for their useful suggestions, which helped to improve the manuscript.

\section{References}

Bader, RG, Gerard, RD, Benson, WE, Bolli, HM, Hay, WW, Thomas Rothwell, W, Jr, Ruef, MH, Riedel, WR, and Sayles, FL (1970) Site 27. In: Initial reports of the Deep Sea Drilling Project. Vol 4, pp 93-123

Bangs, NLB, Westbrook, GK, Ladd, JW, Buhl, P (1990) Seismic velocities from the Barbados Ridge complex: Indicators of high pore fluid pressures in an accretionary complex. Journal of Geophysical Research, 95: 8767-8782

Collot, JY, Lewis, K, Lamarche, G, Lallemand, S (2001) The giant Ruatoria debris avalanche on the northern Hikurangi margin, New Zealand: result of oblique seamount subduction. Journal of Geophysical Research106: 19271-19297

Deville, E, Mascle, A, Callec, Y, Huyghe, P, Lallement S, Lerat, O, Mathieu, X, Padron de Carillo, C, Patriat, M, Pichot, T, Loubrieu, B, Granjeon, D (2015) Tectonics and sedimentation interactions in the east Caribbean subduction zone: An overview from the Orinoco delta and the Barbados accretionary prism. Marine and Petroleum Geology 64: 76103

Dolman, R (2000) Physical properties derived from seismic modeling at the toe of the Barbados accretionary complex. PhD thesis, University of Birmingham, UK

Kristoffersen, Y, Coakley, BJ, Hall, JK, Edwards, M (2007) Mass wasting on the submarine Lomonosov Ridge, central Arctic Ocean. Marine Geology 243: 132-142

Patriat, M, Pichot, T, Westbrook, GK, Umber, M, Deville, E, Bénard, F, Roest, WR, Loubrieu, B, the ANTIPLAC cruise party (2011) Evidence for Quaternary convergence between the North American and South American plates, east of the Lesser Antilles. Geology 39 (10): 979-982

Pichot, T, Patriat, M, Westbrook, GK, Nalpas, T, Gutscher, MA, Roest, WR, Deville, E, Moulin, M, Aslanian, D, Rabineau, M (2012) The Cenozoic tectono-stratigraphic evolution of the Barracuda Ridge and Tiburon Rise, at the western end of the North America-South America plate boundary zone. Marine Geology 303-306: 154-171

Pimm, AC, Burroughs, RH, Bunce, ET (1972) Oligocene sediments near Chain Ridge, northwest Indian Ocean: structural implications. Marine Geology 13: 14-18

Rodriguez, M, Fournier, M, Chamot-Rooke, N, Huchon, P, Zaragosi, S, Rabaute, A (2012) Mass wasting processes along the Owen Ridge (NW Indian Ocean), Marine Geology, 326328: $80-100$

Sigurdsson, H, Sparks, R J S, Carey, S, Huang, TC (1980) Volcanogenic sedimentation in the Lesser Antilles arc. Journal of Geology, 88:523-540

Sumner, R., Westbrook, GK (2001) Mud diapirism in front of the Barbados accretionary wedge: 
The influence of fracture zones and North America-South America plate motions: Marine and Petroleum Geology, 18: 591-613.

Wright, A, (1984) Sediment distribution and depositional processes operating in the Lesser Antilles intraoceanic island arc, eastern Caribbean. In: Biju-Duval, B, Moore, JC, et al. (Eds.), Initial Reports of the Deep Sea Drilling Project. 78A-78B, pp. 301-324. 